\section{Research Article}

(c) 2022 Francis Kwesi Kyirewiah. This is an open access article licensed under the Creative Commons Attribution-NonCommercial 4.0 International License (https://creativecommons.org/licenses/by-nc/4.0/)
\end{abstract}

Received: 24 September 2021 / Accepted: 25 November 2021 / Published: 5 January 2022

\title{
Water Diplomacy: And the Share of the Nile River between Egypt, Ethiopia and Sudan
}

\author{
Francis Kwesi Kyirewiah
}

\author{
Jilin University, \\ Changchun, \\ China
}

DOI: https://doi.org/10.36941/mjss-2022-0004

\begin{abstract}
Water diplomacy across international borders can be a useful tool in solving problems related to the shared water resources of the political entities involved, especially when the interests of the countries are diverse. Water disputes can likely lead to potential conflicts if not properly address in a holistic manner to satisfy all parties concerned. Many discussions about water resources that cut across international borders have focused on their potential for either conflict or cooperation. Africa as a continent with shared resources is not isolated from these enormous challenges concerning the share of natural resources such as water. Africa is generally seen as a fragile region, and the signs of water conflicts in it have begun to appear in clear and dangerous forms. Diplomatic options for settling water disputes and avoiding any potential repercussions seems for the likelihood. Notwithstanding, these options Water Diplomacy has many challenges that limit its effectiveness owing to the deep political tensions among the countries. This study focused on analyzing the concept of water diplomacy and look into the dispute over the share of the Nile River, while highlighting the legitimate right of Egypt, Ethiopia, and Sudan in line with international conventions on water resources.
\end{abstract}

Keywords: Water Diplomacy, Nile River, Conflicts, Egypt, Ethiopia

\section{Introduction}

\subsection{Overview of the Nile River Basin}

The Nile River is shared by ten river basin countries; Egypt, Sudan, Ethiopia, Uganda, Tanzania, Rwanda, Burundi, the Democratic Republic of the Congo, and Kenya. The Nile River covers a distance of $6700 \mathrm{~km}$; consisting of a confluence of the White Nile, which originates from Lake Victoria, and is shared by Uganda, Kenya, and Tanzania, and the Blue Nile that originates from Lake Tana in Ethiopia. These two rivers meet in Sudan to form a single river that crosses Egypt and flows into the Mediterranean Sea. The share of Egypt and Sudan in the level of river water is $65.25 \%$ and $21.75 \%$ respectively, a total of $87 \%$ according to the agreement in force prepared by Britain and reviewed in 1959 (Abdalla, 1971). While the basin countries suffer from water shortages, they are also among the world's 50 poorest nations, except for Kenya and Egypt, as such leaving their populations even more vulnerable to famine and disease. The conflict between the Nile states over the agreements is divided, comprising countries that accept this reality and other countries demanding the cancellation of 
previous agreements. The distribution of Nile water is witnessing a conflict between the source countries and downstream countries, where the latter is calling for downstream countries (Egypt and Sudan) to pay for the share of water they receive and apply the principle of "selling water internationally". In 2010, Ethiopia, Uganda, Rwanda, and Tanzania signed an agreement, after negotiating for nearly ten years, demanding the states along the Nile to return their share of the water. This agreement ignored the absence of Burundi, Congo, Egypt, and Sudan. In the last chapters of this conflict, Ethiopia maintained its sovereign right to develop the water resources within its borders. Its intention to build the Renaissance Dam on the Blue Nile created high tensions between Ethiopia and Egypt (Ashok, 2011).

The majority of experts agree the Renaissance Dam may have negative effects that may be disastrous for Egypt when the dam is fully in operation. Egypt's share of the Nile's water will decrease from 1 to 15 billion $\mathrm{m}^{3}$, thus affecting the agricultural sector, and also affecting electricity supplies in Egypt by $25-40 \%$. Egypt considered that negotiations, diplomacy, and the rules of international law are the basis for managing the issues relating to the Renaissance Dam, Egypt adhered to the diplomatic framework, and negotiations began in the hope of ending the crisis without escalation and tried to convince Ethiopia of the need for scientific and technical alternatives to the dam by referring to the initial specifications 11 billion $\mathrm{m}^{3}$ of water instead of 14 billion $\mathrm{m}^{3} /$ day or create a group of small dams that can generate electrical energy equivalent to what can be generated from the Renaissance Dam (Khartoum agreement, 2015).

Despite the continuous rounds of negotiations and meetings during the period 2011-2018 without achieving positive results between the two parties, as a result of the contradictions on the part of Ethiopia, work on the project continued with international and regional support, through financing or technical help (Mohsen, 2016). The political behavior of Ethiopia, especially after the visit of former US President Barack Obama to Addis Ababa in July 2015, reflects the changing regional balance of power in favor of Ethiopia (Emad, 2016). Egypt's political environment has also not favored the whole situation since the outbreak of the January 25 revolution in 2011. This constituted a factor of weakness and insufficient knowledge on the case by successive new negotiators. In addition to that, Egyptian allies, some Arab Gulf states, Turkey, and Israel, have moved in support of the Ethiopian government technically, financially, and politically. As a result of political differences with the Egyptian state, leading to Egypt losing the influence it has had for a long time on traditional donor powers, such as the World Bank (WB) and the African Development Bank (ADB). Ethiopia does not recognize the majority of the historical agreements that guarantee Egypt's rights to the waters of the Nile River. In addition to the stalling from the Ethiopian side and the lengthy negotiations spanning years without any positive results, it was noted; all that made the negotiations on the Renaissance Dam project one of the longest negotiations is the Egyptian side still insisting on arriving at a solution through negotiation and diplomacy at the expense of other options (Khartoum agreement, 2015).

\section{Definition of Water Diplomacy}

Water Diplomacy has been defined as "the practice of arriving at water management for complicated water cases. It is one of the modern diplomatic styles that rely on a much dense approach to diplomacy towards water crises particularly; that the negotiator groups identify water problems, recognize the points that are for intervention, and suggest potential and sustainable solutions which takes into account all points of view, target values, areas of ambiguity and uncertainty, as well as urgent changes in terms of competition between countries in the areas of water, knowing the needs required in each case"(UNESCO, 2017). In other words, Water Diplomacy is a set of negotiating and diplomatic activities and events that target specific water issues such that cadres and human efforts are mobilized, and the allocation of material and symbolic capabilities are made during a specific period, to achieve strategic goals at the international water level. This is done through a strategic water plan that seeks diplomatic channels through its external moves and activities to arrive at its 
goals (Mohsen, 2017). The term Water Diplomacy is explained as all measures taken by governmental and non-governmental actors towards the prevention of dispute and resolving matters peacefully to encourage cooperation in available water sharing between countries that have transboundary water (Irina and Henk, 2016). The two concepts, Water Diplomacy and cooperation, in the field of water are intertwined, but both of them diverge in their objectives. While Water Cooperation focuses more on technical sides such as water distribution, quality, and availability, Water Diplomacy on the other hand focuses on stabilization, peace, and security. When water is one of the main drivers of armed conflict, it is necessary to include peace strategies as a solution. Stable and sustainable peace is unlikely to last without an effective solution to the water problem (Pane GHL, 2017).

Professor Shafiqul Islam pointed in his article in 2012 "the tools of Water Diplomacy are concentrated in the science community in providing assistance that constitutes diplomatic knowledge and must know well used by negotiators in the areas of Water Diplomacy since science has a major role in changing the negotiating tracks. Scientific and technical knowledge is important in water negotiations, but using scientific information to justify the arbitrariness of political decisions may be counterproductive. For example, scientific information has increased significantly over the past few decades, but the ability of countries to manage water resources has not improved relatively (Susskind and Shafiqul, 2012). International water management is relatively complex. There is an urgent need for Water Diplomatic tools and techniques to deal with complexity and the ability to solve problems; the Arab region still suffers from wide gaps in the application of Water Diplomacy on its International water issues. There is a need to build capabilities and training in applying negotiation theory and skills to solve water disputes (Magdy, 2011). The presence of a skilled coordinator in water negotiations at every stage is extremely important, especially in cases where technical points are being negotiated, such as the case of the Ethiopian Renaissance dam negotiations between Egypt, Sudan, and Ethiopia. Further, it is necessary to have a negotiator with a large scientific and technical background so that he can decipher the owner's interests over the fact (Mohsen, 2017).

The negotiator in Water Diplomatic issues needs skills that can be well practiced through the "art of the possible to achieve national interests", and in addition to these skills a set of auxiliary sciences that will enable the diplomats at the negotiating table to reach effective solutions in this regard. Water Diplomacy is hard work that requires patience and a lot of effort through the acquisition of diversified knowledge like other types of diplomatic work. The negotiating teams should possess the following tools (Magdy, 2011),

Languages: A good knowledge of the official language of all contesting parties' in very important and at least an awareness of the language of the opposite party at the negotiating table. It is important to follow the media and measure the trends of public opinion to know the extent of pressure or support associated with the issue up for negotiation.

Philology: It is important for negotiators who are involved in discussions related to water to be aware of the jurisprudence of the language and to understand the written texts in the language of both parties. Negotiators should fall on historical agreements regarding the sharing of water between upstream and downstream countries, and the circumstances surrounding these agreements.

International law:

Good knowledge of the International water law which consists of a set of principles and standards that provide practical tools for riparian states to determine solutions that are beneficial to all. This law reflects state practices and aims at facilitating discussion and cooperation between them.

Geography: The most important sciences ever in water diplomacy matters; human geography, water geography, political geography, terrain sciences, and climate.

Cartography: the negotiator must be familiar with cartography, which helps in defining the inputs well and arriving at outputs within the framework of the agreement to achieve the purpose of what is required from Water Diplomatic discussions. 


\section{Historical Perspective}

The Nile River, for ages has played a critical role in the geopolitics of Northern and Eastern regions of Africa and has also served as a bond of friendship between countries bordering it. The Nile River has served as a cultural, religious, and commercials linkage between Egypt and Ethiopia for ages to date. However, this historic relationship between these countries is on the verge of total collapse due to the share of the single most important natural resources. The politics currently surrounding the Nile Rivers can be described more or less as a diplomatic confrontation between upstream and downstream riparian countries to the detriment of the entire continent of Africa. This confrontation is not a recent event; however, the construction of the Grand Renaissance dam in Ethiopia seems to have escalated this dispute to new heights. The complexity of the problem is the equal distribution and use of water in the Nile. This is compounded by the existence of old treaties to the use of the Nile and the current demand for full utilization of the Nile resources by the upstream countries.

According to Yacob Aranso and quated by Obengo 2016, he took into account the historical sequence and divided the Nile River Agreements into three categories:

These are:

- Agreements between colonial powers: the Anglo-Italian protocol of 1891, the 1906 agreement, the 1925 Anglo-Italian agreement, and the 1934 agreement between Britain and Belgium (Obengo, 2016).

- Agreements between colonial powers and regional states: the 1902 Anglo-Ethiopian agreement, the 1929 agreement between Britain and Italy, and the 1952 agreement (Obengo, 2016).

The treaties between colonial powers and territorial states: the Anglo-Ethiopian Agreement of 1902, the Agreement of 1929 between Great Britain and Italy, and the Agreement of 1952. Agreements between the independent states of the basin: the 1959 agreement signed by Egypt and Sudan, (Obengo, 2016). The 1993 agreements signed between Ethiopia and Egypt, and the 2010 Comprehensive Framework Agreement signed between the seven countries of the Nile basin (Nile Basin initiate, 2016).

The bilateral agreements in the first and second categories were initiated mainly by the then colonial powers of the basin (Obengo, 2016).

According to Obengo 2016, the 1929 Nile water Agreements allotted to Egypt 48 billion m3 of water at the expense of other bordering countries needs. When the treaty was revised in 1959 Egypt share of the Nile was further increased from 48 billion $\mathrm{m}_{3}$ to 55 billion $\mathrm{m}_{3}$ without taking into consideration the needs and demands of both Ethiopian and Sudan, beside other bordering countries at that time. This increased in water allocation to Egypt pave the way for the construction of the Aswan High Dam, classified as the largest man-made reservoir in Egypt (the United Arab Republic and Sudan, 1959). One of the benefits of the Aswan Dam was that it ended Egypt's dependence on the precarious Nile floods, but led to dire consequences on upstream riparian countries including Ethiopia.

This paper is of the view that the dispute on the Nile River we see today between Egypt and Ethiopia is the result of the 1959 agreement. Ethiopia which was not a party to the agreement felt cheated on the exclusive use of a resource that passes through its territory. Sudan on the other hand had little to say due to its internal political instabilities. To find a common platform to bring lasting solution to the dispute the Nile Basin initiative was launch in 1999.

Among the many roles of the Nile Basin initiative was to provide the riparian countries exclusive avenue for cross-sectional negotiation and diplomacy. The Nile Basin Initiative became operated as a transnational institution until the negotiations of the Cooperative Framework Agreement were finalized and created as a permanent organization. The Nile Council of ministers subsequently became the highest decision-making of the Nile Basin Initiative. Notably among the roles and responsibilities of the Nile Council of ministers were:

To provide political leadership, and ensuring compliance to Nile Basin initiative transition 
systems. Also included in the Nile Basin Initiative was the Nile-TAC, made up of 20 senior government officials two from each of the participating countries responsible for the Nile Basin Initiative. Among the role and responsibilities of Nile-TAC was to provide technical assistance and offer constructive suggestion to Nile-Com on all matters concerning Nile River developments.

Bilateral relations between the governments of Egypt and Sudan improved tremendously in 2009 leading to the grand opening of the Merove Dam in Nubia with Egypt's approval. The opening of the Merove dam by Sudan with Egypt's consent and support cause a wave of great anger among the bordering countries most importantly Ethiopia.

In view of the developments surrounding the exclusive rights of the Nile River and disputes, the five upstream countries (Ethiopia, Kenya, Tanzania, Uganda, and Rwanda), ascribed to a Cooperation Framework Agreements based on their territory rights under international law to the use of the Nile in May 2010. Burundi later joined the group in 2011. These countries insisted on the equitable development of the Nile River based on international territory rights, and not some water rights given by the colonial master to a particular country. The stand taken by the group of six counties who insisted on the natural and territory rights to the Nile River led to the announcement in 2011 by Ethiopia for the construction of five mega-dams on the Blue Nile beginning with the construction of the Grand Renaissance Dam.

Before 2012, the Nile Basin Initiative countries had committed to a long-term strategic plan to conserve the Nile water supplies, however, Egypt has accused Ethiopia of breaching this agreement and followed its water management policy at the expense of other Nile Basin countries and most importantly excluding Egypt and Sudan on it water policy and management.

\section{Demands of competing parties (Egypt, Ethiopia, and Sudan)}

Egypt's concern on the current dispute is the volume of water supply once the dam becomes fully operationalized. Egypt needs assurance from Ethiopia that its required volume of water will not be disrupted by Ethiopia's dam. Water supply from the Nile is vital to all the country's concerns and the construction of critical infrastructure is equally vital to the long-term development agenda of the region. The current growth of population as experience in Africa is estimated to reach its peak in 40 years (Obengo, 2016). With this in mind demand for critical projects are very important for the population. The table below, therefore, highlights electricity accessibility supply among Egypt, Ethiopia, and Sudan from 2016-2020

Table 1: The table below highlights population and access to electricity by the competing countries

\begin{tabular}{|l|l|c|c|c|c|c|}
\hline & Population (million) & $2016(\%)$ & $2017(\%)$ & $2018(\%)$ & $2019(\%)$ & $2020(\%)$ \\
\hline Egypt & 100.4 & 100 & 100 & 100 & 100 & 100 \\
\hline Ethiopia & 114.963 & 43 & 44 & 45 & 48 & 45 \\
\hline Sudan & 42.81 & 49 & 51 & 52 & 54 & 54 \\
\hline
\end{tabular}

Sources: World bank data. (https://data.worldbank.org/indicator/EG.ELC.ACCS.ZS?locations=ET

Egypt from 2016 to 2021 is the only country among the three Nile basin countries that enjoy $100 \%$ access to electricity by the entire population. Every part of Egypt enjoys uninterrupted access to electricity provision for 24 hours per day. Ethiopia and Sudan on the other hand are handicapped with access to electricity coverage. Ethiopians continue to lack access to electricity. As shown in the table from 2016-2021 about 50\% of the entire Ethiopian population does not have access to electricity and this according to development expertise affects the flow of foreign direct investments and development agenda of Ethiopia. Availability of electricity is seen as one of the tools for accelerated development and attraction of foreign direct investment. According to Ethiopian sources the primary motive for the construction of the Grand Renaissance dam is to provide the needed electricity for the 
Ethiopians and to relieve the country of the acute energy shortage and also to export electricity to neighboring countries. Ethiopians development agenda is that the construction of the Dam will increase electricity accessibility to over $80 \%$ of the entire population of Ethiopia.

\section{International Legal Perspective}

\subsection{Water crisis between basin countries from the perspective of international law}

The Tigris and Euphrates rivers gained International characteristics once the Ottoman Empire disintegrated after the First World War and the establishment of both Iraq and Syria. Thus, the two rivers became subject to international laws that applied to International Rivers. The legal system of the Tigris and Euphrates rivers is the set of legal rules that can be used to regulate the exploitation of the waters of the two rivers

\subsection{International rules on the distribution of water between riparian countries}

International law regulates the process of exploiting International Rivers between riparian countries. Several treaties and agreements were issued to regulate the use of international waters between states. The UN published more than 250 treaties in 1963 under the title legislative texts and provisions treaties on the use of International Rivers for purposes other than navigation (Suleiman and Al- Shukri, 2014). The principles of international law were settled long ago, and the most important of these were: the principle of acquired rights, the principle of not harming others, the principle of equal use of the right, the principle of the inadmissibility of arbitrariness in use of the right, the principle of peaceful settlement of disputes, the principle of good neighborliness, and the principle of good faith (Berber, 1961). Through these principles, there was no doubt that states had the right to the use of shared International River that flows through their territory, but these countries differ in their outlook to nature of use, there are three theories that deal with this right, namely

\subsection{The Theory of Complete Territorial Sovereignty}

This theory grants all states the right to practice sovereignty on the whole area of the International Rivers that run through its territory, to establish projects, and to use the IR water as long as it runs across their lands, regardless of the consequences on the other riparian states in the basin. This theory was based on what is known as the Harmon Doctrine, according to the US Attorney General (Jadson Harmon), in light of the conversions made in 1896 by the U.S as part of the Rio Grande River which was the center of conflict between the US and Mexico. The USA justified that international law rules do not obligate it to share the water of the aforementioned river with Mexico and, and has full legal right and sovereignty over the portion of the river within its territory (Mizanur, 2009).

\subsection{The Theory of Complete Regional Integration}

This theory does not give riparian states the right to change the natural course of a river that flows through its territory, and emphasizes the principles of good-neighborliness; is of relevance to the principle of fair and reasonable utilization of international water, it also asserts that no country has the right to take unilateral action which affects the other countries on the basin (Mansour, 1996).

\subsection{Limited Regional Sovereignty Theory}

This theory states that a country is free to use water flowing through its lands, provided that such use does not cause significant harm to the interests of other basin countries. This allows the basin 
countries to enjoy the rights and obligations jointly in the use of International River therefore, this theory is more acceptable for scholars in international law (Hassan and Tariq, 1997).

The most important rules for the use of international water are the "Helsinki Rules" that emanated from the fifty-second conference of the international law Association in 1966. It is worth noting that the decisions of the international law Association regulating the rules of Helsinki and other decisions issued by legal committees are legal sources of the International Court of Justice, but they are not compulsory, although it is an important legal system of rules governing the use of International Rivers for navigational purposes. The "Helsinki Rules" included 37 articles that contained general principles that later became influential at the regional and international levels (Salman, 2007). There are also many international agreements to regulate the uses of International River water for purposes other than navigation, the most prominent of which are:

Vienna Convention (1815): It was the first international convention to establish a legal principle; The Rivers that pass through the territory of more than one country are subject to international legal standards.

Peace treaties concluded after the First World War: This included the Barcelona Treaty in the year 1921 and the Geneva Convention of 1923; these treaties dealt with energy development and waters affecting more than one country. Also, the treaties defined the uses of IR water for purposes other than Navigation and affirmed the freedom of states to use the water that passes through their territories within the rules of international law (Rahaman, 2009).

UN Conference held in the Argentine city of Mar del Plata in March (1977): Confirmed existing general principles of international law are generally acceptable, governing the use of water resources jointly, for development, and management in the absence of bilateral or multilateral agreements. The highlights from this conference included the concern of the world owing to the problem of water availability and quality, and recommendations were made covering eight main areas; water resources assessment by using water effectively, environment, health and pollution control, planning and policy management, natural hazards of the mass media, education, training and research, regional cooperation, and international cooperation (Report of UN conference on water, 1977).

UN Convention on International Rivers 1997: The UN General Assembly adopted in its Fiftyfirst session on 21 May 1997 the framework agreement, which is one of the most important international agreements in this field. This includes the basic rules under which water resources are shared from rivers -in general- for agricultural, industrial, and drinking purposes. The agreement consists of (33) articles that represent a set of main general principles and related provisions about the usage of river water for purposes other than navigation (Mohamed, 2012).

Legal principles have emerged in regulating the exploitation of International Rivers, the most important of which are; First, it is prohibited for any country to make any changes to the watercourse in a way that negatively affects the rights of other riparian states except after an agreement is reached between them, and balancing benefits with harms. Second: the riparian countries are obliged to consult and exchange information regarding the plans of each country (UN yearbook, 1985). Third: the riparian countries have the right to use the watercourse based on full equality in rights. Fourth: the fair and reasonable distribution of common water and respect for the acquired and historical rights of each country, and to refrain from engaging in any work that might be affecting the rights and interests of the basin countries. These principles place international responsibility on each country that is trying to bring a change in the water from the IR or modification of its course in a way that impacts the quantity and quality of water (Sultan, 1976).

\section{Other Solutions to International Water Dispute}

Despite the improvement of political relations between the three countries its reflection on understanding and cooperation are still limited in reaching a final and fair agreement for the water resources. This issue is still a hotbed of tension between the riparian countries, as Egypt sees the 
actions of Ethiopia as contravene to international agreement of which Ethiopia claims was not a party. Besides, Water Diplomatic efforts hasn't achieve its goal to solve the dispute to reach a final agreement, and the main reason is that the entrench position taken by all parties on the territorial right to the Nile river. The political history of the region confirms that the freshwater variable has become an essential component of security as it is an important factor in the economy. Many proposals were made in which this dispute could be resolved after setbacks of diplomatic attempts (Taya Muhammad, 2006). Among the proposals include:

\subsection{Egypt, Ethiopia, and Sudan solution and the principle of good-neighborliness}

Egypt, Ethiopia and Sudan all have concern that the dispute has a political dimension to it and requires a political decision at the highest level due to its interwoven and association with other problems (Abdulaziz, 1996). Their suggestion to resolve the problem was to refrain Ethiopia from cutting down the volume of water supply to Egypt and the possibility of flooding in Sudan when the dam become fully operationalized. Furthermore, all countries called for a resolution of the water dispute with a good intention, relying on norms and international law and the principle of goodneighborliness (Tariq, 1994).

The first and basic step towards resolution of the crises adopted by the Egypt-Ethiopian side was for Ethiopia to ensure that the volume of water required by Egypt will not be reduced once the dam becomes operationalized at full capacity. At the same time basin serious and urgent discussions between the riparian countries at the foreign ministry level must continue to ensure agreement on the final distribution of the basin water, and investment terms" (Jamalou, 1996). However, the Egypt attitude toward the Nile river is still unchanged and insistence of the colonial agreement. Egypt considered the problem as a technical issue, which can be solved according to the principle of apportioning water usage, Egypt also saw no need for the adoption of international law or the laws adopted by the General Assembly (Zakaria, 1994). Although there are treaties between Egypt and Sudan that are recognized by both sides with the internationalism of the basin, Ethiopia considers them null because they were concluded during the period of the British mandate over Egypt with Ethiopian's inputs. Egypt also asserts there are protocols, notes, and meetings between the basin countries that confirm the internationalism of the two rivers, and Ethiopia have recognized in more than one treaty that the two rivers are international and subject to international law like, protocol 1987 between Egypt and Sudan, which is registered with the General Secretariat of the UN on 1 June 1993. Egypt insists if Ethiopia continues to reject the international feature of the rivers, then the Rhine, Senegal, the Nile, and other rivers will not be considered as international rivers (Jamalou, 1996).

\section{Application of Theories on Nile River Disputes}

\subsection{The theory of complete territorial sovereignty}

This theory grants all states the right to practice sovereignty on the whole area of the International Rivers that run through its territory, to establish projects, and to use the IR water as long as it runs across their lands, regardless of the consequences on the other riparian states in the basin. This theory was based on what is known as the Harmon Doctrine, according to the US Attorney General (Jadson Harmon), in light of the conversions made in 1896 by the U.S as part of the Rio Grande River which was the center of conflict between the US and Mexico. The USA justified that international law rules do not obligate it to share the water of the aforementioned river with Mexico and, and has full legal right and sovereignty over the portion of the river within its territory (Mizanur, 2009). 


\subsection{The theory of complete regional integration}

This theory does not give riparian states the right to change the natural course of a river that flows through its territory, and emphasizes the principles of good-neighborliness; is of relevance to the principle of fair and reasonable utilization of international water, it also asserts that no country has the right to take unilateral action which affects the other countries on the basin (Al-Adly, 1996).

\subsection{Limited Regional Sovereignty theory}

This theory states that a country is free to use water flowing through its lands, provided that such use does not cause significant harm to the interests of other basin countries. This allows the basin countries to enjoy the rights and obligations jointly in the use of International Rivers or waters, therefore, this theory is more acceptable for scholars in international law (Shalaby and Tariq, 1997).

\subsection{Shared Resources and Common vision}

The countries bordering the Nile Basin have different interests, demand, and needs for the use of the river Nile (Nile Basin initiative, 2015). The existence of the Nile River should be regarded as a shared resource for all countries bordering it, and this calls for a common vision on the use, development, and management of the Nile resources to meet the aspirations of all countries. Any Shared resources demands common vision, and responsibilities for the management of the resources. The Nile basin cooperation anticipates the promotion of shared resources and a common vision for the needs of all countries concern.

\section{Conclusion}

The preliminary agreement by all bordering countries on the construction of the Grand Renaissance Dam in February 2015, seems to be a step in the right direction on the share of the Nile water, however, future cooperation will determine the future of Egypt-Ethiopia-Sudan relations until they all reach a final agreement, settlements that guarantee each state with its water rights according to the international agreements on water distribution. In addition, the application of international regulations to the Nile River, considering Ethiopia and Sudan are from the riparian countries in the basin will also be useful in this case. Therefore, it is necessary to have cooperation between these three countries, not only to avoid conflict but also to protect the natural systems that form an essential part of the regional economies. Based on the above, a set of recommendations can be reached:

1. The importance of coordination between Egypt and Ethiopia in all political, economic, and social fields through one integrated water management, and rationalization of consumption of available water resources. This should be done through the establishment of media and awareness campaigns, and the development of plans and programs for using advanced techniques for the development of water resources. Also, ministries concerned with the water field in both Egypt and Ethiopia should create new policies to compensate for water instead of the basin water, which suffers from scarcity and evaporation and is threatened by drought. It should focus on wastewater purification, and the establishment of desalination plants to desalinate saltwater.

2. Activating diplomatic channels between the riparian countries to conclude a tripartite agreement, based on the recommendations from conferences, water bodies, and international law. Negotiating teams with a specialty in legal, economic, and technical skills are to be formed to reach a final agreement that preserves the water rights for all parties.

3. Activate the African Union's diplomatic and political effort at the regional and international levels to ensure and protect Nile water interests and enhance negotiating capabilities for shared waters with all countries, provided this is done based on the rules of international law 
and agreements. Therefore the African Union must be invited to consider formulating an African Union legal framework concerning common watercourses to preserve the integrity of relations between riparian countries.

4. Mobilization of international forces to internationalize the water crisis and advocate for the water rights due Ethiopia and Sudan. International and legal organizations must step up to take a stand that Egypt's insistence has no international legal basis because, from a legal standpoint, the principle of not harming others can not apply without specifying the share due to each of the three riparian countries in the basin.

5. Using the alternative economic incentives system as it is a suitable approach to solving the outstanding water crises between the basin countries, and activating the role of UN organizations to help economically poor countries like Sudan, suffering from war and shortage water, to adopt the economic incentives system with the upstream country. As relevant UN organizations can contribute to financing the alternative economic incentives system by providing technical expertise and setting up water projects for the benefit of all the countries in the basin.

6. Future policies developed by Ethiopia and Sudan geared towards building more dams on the rivers with approval from African Union and with support from the international community. However, certain unfortunate comments by former President America's Trump to that "Egypt may blow up the dam" were comments in bad taste to the water dispute resolution.

\section{Reference}

"Report of UN Conference on Water (Mar del Plata 1977)" 25 Feb, Tue: 2:25 am, p: 54 https://tinyurl.com/thx7plr.

Abdullah. Al-Droubi "The positives of cooperation between the countries of the Tigris and Euphrates basins to make optimal use of their water resources" report, the Scientific Forum on the Arab Water Security Strategy, Naif Arab University for Security Sciences, Riyadh, 2011, p: 36.

Abu Al-Nour. Mohammed Mohsen "Water diplomacy: the Renaissance Dam as a model", The Egyptian Institute for Studies,(2017), p: 4.

Abu Al-Nour. Mohammed Mohsen "Water diplomacy: the Renaissance Dam as a model", The Egyptian Institute for Studies, (2017), p: 4.

Abu al-Nur. Muhammad Mohsen "Water Diplomacy: The Renaissance Dam Model" Egyptian Institute for Studies), February 2016 (, pp: 9-10.

Al-Majdoub. Tariq "Current Arab-Turkish Relations (Arab-Turkish Cooperation in the Field of Infrastructure Projects: Water and Electrical Energy" Journal of Arab Future, Issue (188), Beirut, 1994, p: 80.

Al-Masry.Abdulaziz "The Reality of the Water Problem between Syria and Iraq with Turkey" Journal of Palestine's voice, Damascus, No. 240,(1996), p: 22.

Al-Rashidi. Hala Ahmed Mohamed "International Management of Shared Water Resources: A Study in the Light of the Provisions of the UN Convention of 1997 Concerning International Watercourses" Faculty of Economics and Political Science - Cairo University, International Law Forum, (2012),p: 10.

Al-Rubaie. Sahib Water projects in the ME (Damascus, AL-hasad House for Publishing,2003), p: 181.

Al-Sebahi. Zakaria Water in International Law and the Arab Water Crisis, (Damascus, Translation and Publishing Dar Tlas for Studies, 1994), p: 130.

Berber. F. J" Rivers in international law" Trans from German by R. K. Batstone. (London: Stevens \& Sons Ltd.; New York: Oceana Publications. American Journal of International Law. Vol. 55, Issue. 3, (1961), p: 208.

Bokova. Irina and Ovink. Henk "The Multi-track Water Diplomacy Framework a Legal and Political Economy Analysis for advancing cooperation over Shared Waters" The Hague Institute for Global Justice, (2016), p:13.https://tinyurl.com/v7c2ddg.

Bokova. Irina andOvink. Henk "The Multi-track Water Diplomacy Framework a Legal and Political Economy Analysis for advancing cooperation over Shared Waters" The Hague Institute for Global Justice, (2016), p:13.https://tinyurl.com/v7c2ddg.

H Verhoven, Black gold for blue gold? Sudan's oil, Ethiopia's water and regional integration, London: Chatham House, 2011.

Hamdi. Emad "The Egyptian negotiating position in the Renaissance Dam crisis: challenges and options" Journal of international politics, No. 213, 2016, 13 March, Fri 4:53 pm.https://rawabetcenter.com/archives/19026. 
Hamid. Sultan, Public International Law in peacetime (Cairo, Dar Al-Nahda Arabic. 1976), p: 397.

Hardo Center for Supporting Digital Expression" Khartoum agreement and the loss of the rights of Egyptians at the gates of the Renaissance Dam" Cairo,) 2015(, p: 18. 13 March, Fri 15:19. www.hrdoegypt.org.

Hardo Center for Supporting Digital Expression, "Khartoum agreement and the loss of the rights..." pp: 22-24.

Hassan. Shalaby and Majzoub. Tariq "Turkish and the Euphrates Water and international Law" In Water in the ME: legal and political spaces and economics Mallat, Shibli, (Damascus, publications of the Syrian Ministry of Culture, 1997), p: 227.

Hassanm. Shalaby and Majzoub. Tariq "Turkish and the Euphrates Water and international Law" In Water in the ME: legal and political spaces and economics Mallat, Shibli, (Damascus, publications of the Syrian Ministry of Culture,1997), p: 227.

Henry.A. Magdy "Water Diplomacy: a tool for Enhancing Water Peace and Sustainability in the Arab Region", Second Arab Water Forum Theme 3: "Sustainable and Fair Solutions for the Transboundary Rivers and Groundwater Aquifers" Cairo,(2011), P: 21.

Henry.A. Magdy"Water Diplomacy: a tool for Enhancing Water Peace and Sustainability in the Arab Region", Second Arab Water Forum Theme 3: "Sustainable and Fair Solutions for the Transboundary Rivers and Groundwater Aquifers" Cairo,(2011), P: 21.

https://data.worldbank.org/indicator/EG.ELC.ACCS.ZS?locations=ET

I. H. Abdalla "The 1959 Nile Waters Agreement in Sudanese-Egyptian Relations" Journal of Middle Eastern Studies, (Published by: Taylor \& Francis, Ltd) Vol. 7, No. 3, (1971), pp: 329-341.

Jamalou. Ali, Water dispute (1996), p: 42.

Jamalou.Ali Water dispute in the ME (Beirut, Riyad Al-Rayes for Books and Publishing,1996), p: 46.

Joel Okundi Obengo (2016) Hydropolitics of the Nile: The case of Ethiopia and Egypt, African Security Review, 25:1, 95-103, Lawrence. Susskind and Shafiqul, Islam "Water Diplomacy, Creating Value and Building Trust in Transboundary Water Negotiations" Journal of Science and Diplomacy, Vol.1, issue.3, (2012), pp: 1-7.

Lawrence. Susskind and Shafiqul, Islam"Water Diplomacy, Creating Value and Building Trust in Transboundary Water Negotiations" Journal of Science and Diplomacy, Vol.1, issue.3, (2012), pp: 1-7.

Mansour. Al-Adly Water Resources in the ME, Conflict or Cooperation, (Cairo, Arab Renaissance House,1996), p: 105.

Mansour. Al-Adly Water Resources in the ME, Conflict or Cooperation, (Cairo, Arab Renaissance House, 1996), p: 105.

Many writers "Preventing Conflicts, Fostering Cooperation: The many Roles of Water Diplomacy", (ICWC), United Nations educational, scientific and cultural organization.(2017), p: 19

Muhammad. Mizanur Rahaman "Principles of international water law: Creating effective transboundary water resources management", Journal of Sustainable Society, Vol. 1, No. 3, (2009), p: 8.

Nile Basin Initiative, Nile Basin Initiative, www.nilebasin.org/index.php/about-us/nile-basin-initiative, (accessed February 2021).

Nile Basin Initiative, Nile Basin Initiative, www.nilebasin.org/index.php/about-us/nile-basin-initiative, (accessed February 2021).

Pane.GHL"Hydro-Diplomacy for Water, Peace, and Security beyond Shared Water Management" 27 Feb, 2 am2o17,p: 2.https://tinyurl.com/s9da4bj.

Pane.GHL"Hydro-Diplomacy for Water, Peace, and Security beyond Shared Water Management" 27 Feb, 2017,p: 2.https://tinyurl.com/sgda4bj.

Rahaman.Muhammad Mizanur "Principles of international water law: Creating effective transboundary water resources management" Journal of Sustainable Society, Vol. 1, No. 3, (2009), pp: 207-223.

Rahaman.Muhammad Mizanur "Principles of international water law: Creating effective transboundary water resources management" Journal of Sustainable Society, Vol. 1, No. 3, (2009), pp: 207-223.

Salman. Taya Muhammad "Limited Water Resources and International Conflict, a Survey Study of Theoretical Trends" Journal of Al-Nahda, Cairo University No. 2, Vol. 7, (2006).

Salmanim.Salman "The Helsinki Rules, the UN Watercourses Convention and the Berlin Rules: Perspectives on International Water Law", Journal of Water Resources Development, Vol. 23, No. 4,(2007), pp: 625-640.

Suleima.Samir Hadi- Kitab. Al-Shukri, "International rules governing water sharing and the problem of basin water distribution Tigris and Euphrates between Turkey and Iraq" Al Aref Publications Est (2014), p: 4.

Swain. Ashok"Challenges for water sharing in the Nile basin: changing geopolitics and changing climate" Hydrological Sciences Journal, Vol. 56, Issue. 4, (2011), pp: 687-702.

The United Arab Republic and Sudan agreement (with annexes) for the full utilization of the Nile waters, Treaty Series, vol. XCIII (1959), Cairo: League of Nations, 1959.

United Nations"YEARBOOK OF THE IL COMMISSION 1983" New York, vol. 2, part. 1, (1985), p: 175. 